\title{
Effect of Common and Dominant Seed-Borne Fungi on Protein Content of Pulses
}

\author{
Ashok S. Kandhare \\ Department of Botany, K.M.C. College, Khopoli, India \\ Email address: \\ ashokkandhare@gmail.com \\ To cite this article: \\ Ashok S. Kandhare. Effect of Common and Dominant Seed-Borne Fungi on Protein Content of Pulses. American Journal of Biological and \\ Environmental Statistics. Vol. 2, No. 4, 2016, pp. 41-43. doi: 10.11648/j.ajbes.20160204.13
}

Received: August 1, 2014; Accepted: August 29, 2014; Published: January 16, 2017

\begin{abstract}
Seeds are inhabited by seed mycoflora. Seed mycoflora influence seed texture, physiology and content. Some seed-borne fungi may be symbiotic to the seed germination where as some cause pathogenesis. Similarly, seed-borne fungi affect adversely to nutritive value of pulses. Biodegradation of protein content of pulses by their common and dominant seedborne fungi like Aspergillus flavus, A. niger, A. fumigatus, Drechslera tetramera, Fusarium moniliforme, Rhizopus stolonifer etc. has been reported through artificial infestation of the pulses Green gram, Black gram, Chick pea and Pigeon pea. Results reveal considerable degradation in protein content of the test pulses.
\end{abstract}

Keywords: Seed-Borne Fungi, Seed Content, Pulses

\section{Introduction}

Pulses are rich in protein, essential amino acids, and micronutrients. Green gram, Black gram, Chickpea, and pigeon pea are rich in protein content i.e. $24 \mathrm{~g}, 24 \mathrm{~g}, 20.5 \mathrm{~g}$, and $20.4 \mathrm{~g} / 100 \mathrm{~g}$ of seeds respectively.

Total seventeen fungi (Alternaria tenuis, Alternaria alternate, Aspergillus carbonarius, A. flavus, A. niger, A. nidulans, A. fumigatus, Cladosporium spp., Colletotrichum truncatum, Chaetomium globosum, Curvularia lunata, Drechslera tetramera, Fusarium moniliforme, Fusarium oxysporum, Penicillium spp., Rhizopus stolonifer, Macrophomina phaseolina) were isolated from the test pulses, on agar plates and moist blotters. Agar plates showed more fungal incidence compared to moist blotters. Among seventeen fungi isolated and identified, the common and dominant fungi were A. flavus, A. fumigatus, A. niger, Drechslera tetramera, Fusarium oxysporum and Rhizopus stolonifer. Pulses are artificially infected by fungal pathogens common and dominant seed-borne fungi. These fungi are found to be adversely affecting protein content of the pulses. Seed of Green gram, Black gram were degraded due to Aspergillus flavus and Fusarium semitectum [1]. There was loss in protein content due to seed-borne fungi of groundnut [2]. Aspergillus niger, A. flavus, Fusarium moniliforme caused decrease in protein content of the Arhar seeds [3].
Seed germination and seedling growth was retarded due to seed-borne fungi in vigna radiate L. [4]. Similarly, changes in sugar content of mango pulp due to different isolates of Aspergillus niger [5].

\section{Materials and Methods}

\subsection{Collection of Samples}

Seed samples of Green gram, Black gram, Chickpea, and Pigeon pea were collected from field, market places from market; field of district Nanded; Maharashtra, India by following standard methods of sampling [6]. A composite seed sample for each of the pulse crop was made by mixing the individual seed sample together and preserved in gunny bags at room temperature during the studies.

\subsection{Preparation of Spore Suspension}

The isolated seed-borne fungi of test pulses were identified on the basis of colony character, texture, color and sporulation with naked eye and microscopically. Identifications were confirmed with the help of authentic manuals [7-10]. Pure cultures of the identified fungi were made and maintained on potato dextrox agar (PDA) slants. Spore suspension of common and dominant seed-borne fungi of pulses were prepared separately by adding $10 \mathrm{ml}$ of sterile 
distilled water into the sporulating pure cultures of seedborne fungi of pulses; maintained on PDA slants for seven days at room temperature. The slants were shaken and content was filtered through muslin cloth to separate mycelium and spore. The filtrate thus obtained was used as spore suspension.

\subsection{Estimation of Protein}

Protein estimation was done by Lowry's method [7], using spectrophotometer. Standard calibration graph was prepared and based on it; protein content of each test pulse was estimated.

\subsection{Reagents Used}

i. $2 \%$ sodium carbonate $\left(\mathrm{Na}_{2} \mathrm{CO}_{3}\right)$ in $0.1 \mathrm{~N} \mathrm{NaOH}(100 \mathrm{ml}$ distilled water $+0.4 \mathrm{~g} \mathrm{NaOH}+2 \mathrm{~g}$ sodium carbonate) (Reagent-a).

ii. $0.5 \%$ copper sulphate $\left(\mathrm{CuSO}_{4} 5 \mathrm{H}_{2} \mathrm{O}\right)$ in $1 \%$ sodium potassium tartarate $(100 \mathrm{ml}$ distilled water $+1 \mathrm{~g}$ sodium potassium tartarate $\left.+0.5 \mathrm{~g} \mathrm{CuSO}_{4}\right)$ (Reagent-b).

iii. Alkaline copper solution: $50 \mathrm{ml}$ of reagent-a $+1 \mathrm{ml}$ of reagent-b (freshly mixed solutions used)

iv. Folin- Ciocalteau reagent (Phenol reagent): The commercially available reagent was diluted with equal volume of water at the time of use.

v. Standard protein solution (stock solution): $20 \mathrm{mg}$ gelatin dissolved in $20 \mathrm{ml}$ distilled water. The content transferred to $100 \mathrm{ml}$ volumetric flask and volume made to $100 \mathrm{ml}$.

\subsection{Measurement of Optical Density (OD) and Preparation of Standard Calibration Graph}

Five sterilized borosil glass test tubes were serially arranged on test tube stand with sequential number labels on it. The protein stock solution was pipetted out with graduated pipette as $0.2,0.4,0.6,0.8$, and $1.0 \mathrm{ml}$ added to the test tubes sequentially from $1^{\text {st }}$ test tube to $5^{\text {th }}$ test tube respectively. The volume of each of the test tube was made to $1 \mathrm{ml}$ with distilled water. A tube with $1 \mathrm{ml}$ of distilled water and with $0.00 \mathrm{ml}$ of protein solution served as blank. $5 \mathrm{ml}$ of alkaline copper solution was added to all the test tubes including blank. The test tubes were shaken thoroughly and allowed to stand for ten minutes at room temperature. $0.5 \mathrm{ml}$ of diluted FolinCiocalteau reagent was added rapidly with immediate mixing; it resulted into production of blue colour in 30 minutes.

For OD measurement, spectrophotometer (Systronic Type106) was set to zero with the help of blank solution at 660 $\mathrm{nm}$. OD of each test solution was recorded separately one by one and standard graph was prepared by plotting OD versus protein quantity $(\mathrm{mg})$.

\subsection{Extraction and Estimation of Protein Content of Seeds of Pulses}

One gram of seed of each four test pulses Green gram, Black gram, Chickpea and Pigeon pea were ground into fine flour with mortar and pestle separately. The powder of each pulse was extracted separately with an aliquot of ethanol and petroleum ether $(2: 1 \mathrm{v} / \mathrm{v})$ mixture with constant stirring for few minutes. The sediments thus obtained were washed again with ether. The solvents of each seeds of pulses were filtered in conical flasks separately. The residue was collected and filtrated contents; containing lipids, carbohydrates and other non-proteinaceous compound was discarded. The collected residues of each pulses seeds was dried at room temperature to remove all traces of ether and dissolved in $10 \mathrm{ml}$ of $20 \%$ Trichloro acetic acid (TCA). The resultant mixture was kept at $4{ }^{\circ} \mathrm{C}$ for four hours. After cold treatment, the mixtures were subjected to centrifugation at $8000 \mathrm{rpm}$ for ten minutes The precipitates obtained after centrifugation was dissolved separately in $5 \mathrm{ml}$ of $0.1 \mathrm{~N} \mathrm{NaOH}$ and made up to $50 \mathrm{ml}$ with distilled water. These were treated as protein extracts of each of the test pulses. $0.1 \mathrm{ml}$ and $0.2 \mathrm{ml}$ protein extracts thus obtained were taken in different test tubes and similar procedure was followed as used earlier for standard proteins. Protein content of each test pulse was deduced from the standard graph of protein.

\section{Result and Discussion}

The results in the Table show that all common and dominant seed-borne fungi of pulses caused reduction in protein content of all test pulses in more or less quantity.

In all test pulses, Fusarium moniliforme caused maximum reduction in protein content followed by Aspergillus niger, $A$. flavus. Minimum loss in protein was reported in Green gram, Chick pea, and Pigeon pea by Rhizopus stolonifer, in Black gram by Aspergillus fumigatus and Drechslera tetramera. This reduction in protein content of test pulses by the seedborne fungi proves their proteolysis efficacy.

Srivastava Sweta reported maximum protein content of Jatropha crucas L. was reduced by the seed-borne fungi Fusarium chlamydosporum [8]. Seed-borne fungi Aspergillus flavus, A. niger, Macrophomina phaseolina, Fusarium oxysporum caused reduction in carbohydrates and proteins [9]. Vegetable seeds were affected adversely due to association of seed-borne fungi during storage [10]. A gradual loss of carbohydrate (both soluble and insoluble) content and loss of protein was recorded due to storage fungi of maize, groundnut and soybean [11]. A dominant fungi Aspergillus flavus on Arachis hypogeal caused quantitative and qualitative damage, reducing sugar and oil content of the seeds [12].

\section{Conclusion}

Seed mycoflora of pulses is responsible for seed degradation and especially in deterioration of the seed content. Protein content degradation naturally makes seed low in protein rendering seed feeble for germination and seedling emergence. Such enfeebled seeds may lose vigor and may not show normal germination. In order to protect seeds from adverse effects of seed mycoflora natural biochemicals are relevantly desirable. Some botanicals could be harnessed as pre treatment of seeds before sowing; 
phytochemicals could be used as seed mycoflora protectant.

Table 1. Effect of common and dominant seed-borne fungi on total protein content of pulses. (After ten days of incubation).

\begin{tabular}{llllll}
\hline \multirow{2}{*}{ Sr. No. } & Infestation by common and dominant & \multicolumn{4}{l}{ Total protein content of seeds (mg/g of seeds) } \\
\cline { 3 - 6 } & seed-borne fungi & Green gram & Black gram & Chick Pea & Pigeon pea \\
\hline 1 & Aspergillus flavus & 121 & 120 & 107 & 136 \\
2 & Aspergillus fumigatus & 130 & 136 & 158 & 159 \\
3 & Aspergillus niger & 124 & 123 & 146 & 153 \\
4 & Drechslera tetramera & 122 & 136 & 163 & 125 \\
5 & Fusarium moniliforme & 120 & 131 & 162 & 170 \\
6 & Rhizopus stolonifer & 133 & 140 & 168 & 173 \\
7 & Control & 136 & & & \\
\hline
\end{tabular}

\section{References}

[1] Biligrami, K. S., T. Prasad, Jamaluddin, and A. K. Roy, "Studies on the deterioration of some pulses by fungi", Indian phytopath, Vol. 29 (3), 1976 pp. 374-377.

[2] Nager, H. L. and S. K. Chauhan, "Storage rotting, fungi and chemical composition of groundnut kernels", Indian J. microbiol, Vol. 17 (3), 1977 pp. 116-117.

[3] Sinha, M. K. and T. Prasad, "Deterioration of Arhar seeds by Aspergillus flavus "Indian phytopath, Vol. 30 (1), 1977, pp. 7072.

[4] Sinha, M. K. and T. Prasad, "Effect of fungal metabolites on seed germination, microbial association and seedling growth of Mung”, Indian phytopath, Vol. 34 (4), 1981 pp. 515-517.

[5] Gadgil, D. P. and Chavan, A. M., "Changes in sugar contents of mango pulp due to different isolates of Aspergillus niger", Geobios, 36, 2009, pp. 211-212.

[6] Srivastava Seweta, Srivastva mnisha, Kumar ravindra and Sinha Asha, "Effect of seed-borne mycoflora on protein and amino acid content of Jatropha curcas L. seeds during storage", Vegetos- international journal of plant research, vol.26 (2), 2013 pp 271-279.

[7] Mukadam, D. S., "The illustrated kingdom of fungi (some selected genera)", Published by Akshar Ganga prakashan, Aurangabad, India1997.
[8] Subramanian, C. V., "Hypomycetes: An account of Indian species. Except Cercospora". ICAR, New Delhi. 1971.

[9] Neergaard, P. and S. B. Mathur, "University teaching of seed pathology", published by Prasaranga, University of Mysore, India, 1980.

[10] Jha, D. K., "A text book on seed pathology", Vikas publishing house pvt. Ltd. New Delhi, 1993; reprint 1995.

[11] Neergaard Paul, Seed pathology, Vol. John Villy, sons, N. Y., 1977.

[12] Wadje, S. S. and M. M. V. Baig, "Introduction to Plant Physiology, Biochemistry and Biotechnology", Satyajit Prakashan, Nanded, 2006.

[13] Ushamalini, K. Rajappan and Kousalya Gangadharan, "Changes in the biochemical constituents of Cowpea due to see-borne fungi", Indian phytopath, Vol. 51 (3), 1998 pp. 258260.

[14] G. Sethumadhava Rao, Laxmi Narayana, B. Bhadraiah and C. Manoharachary, "Biochemical changes due to fungal infestation in stored seeds of some vegetable crops, Indian phytopath, Vol. 67 (2), 2014 pp. 159-163.

[15] Kashinath Bhattacharya and Subrata Raha, "Deteriorative changes of maize, groundnut and soybean seeds by fungi in storage", Mycopathologia, Vol. 155(3), 2006 pp. 135-141.

[16] Naikoo Abbas, Wani Mubashir, Nazir Ahemad Bhat, WaheedU-Zmeena, Md. Suliman Dar and Mohamood Ahmad Tak, "Effect of seed-borne mycoflora on the quality of three varieties of Arachis hypogeal", Vol. 3(1), 2013 pp. 35-42. 